\title{
RESTRICTIONS AGAINST ALIENATION IN AGREEMENTS RELATING TO OIL AND GAS INTERESTS \\ ROBERT E. NOWACK*
}

\begin{abstract}
This paper outlines the legal characterization of certain provisions restricting alienation of various oil and gas interests and analyzes the legal position of an assignee where the assignment to him results in a breach of a provision restricting assignment by the assignor.
\end{abstract}

\section{INTRODUCTION}

Counsel involved in oil and gas transactions regularly encounter agreements containing restrictions against the alienation of oil and gas interests. Rights of first refusal and requirements for consent to assignments of oil and gas rights are frequently found in oil and gas leases, subleases, farmout and farmin agreements and operating agreements. The legal problems which these restrictions on alienation create are most of ten confronted in the course of financing or in the purchase and sale of oil and gas rights.

The legal problems created by provisions restricting alienation of oil and gas interests present themselves in many different situations in practice. In order to give a focus to the problems, this paper contemplates, unless otherwise stated, that the holder of a freehold oil and gas lease in Alberta (the "farmor") has entered into an agreement (the "farmout agreement") with a person (the "farmee") under which the farmee is required to pay for the cost of drilling a well to earn a 50 percent net working interest in the lease. In addition, the farmee has, some time after entering into the farmout agreement, entered into an agreement (the "participation agreement") with a third party ("A") whereby A agrees to pay a portion of the farmee's obligations under the farmout agreement, in return for which the farmee agrees to assign to A, or hold in trust for $A$, an interest in the lease. The participation agreement constitutes both an agreement to assign the farmee's interest and a declaration that the farmee holds such interest in trust for A. In addition, the farmee agrees to operate for the purposes of drilling the well and thereafter under an operating agreement to which only the farmor and farmee are parties.

The following are typical examples of provisions restricting alienation, which might be found in a freehold oil and gas lease or in a farmout agreement, and a provision respecting default which might be found in an oil and gas lease.

\section{A. ASSIGNMENT RESTRAINT CLAUSES}

1. The farmee is expressly prohibited from encumbering or granting any legal or equitable interests in this Agreement, the said lands or any portion thereof.

2. . . a party shall not assign. sell or dispose of any of its participating interest in the joint lands ... without first complying with the following provisions:

The party wishing to make the assignment, sale or disposition shall notify the other parties and obtain their written consent, which shall not be unreasonably with held. 


\section{B. DEFAULT CLAUSE}

In case of the breach or non-performance on the part of the Lessee of any covenant. proviso, condition or stipulation herein contained or incorporated by reference herein and which shall not have been waived by the Lessor, the Lessor may give the Lessee written notice requiring it to remedy such default, and in the event of the Lessee failing to remedy such default within a period of thirty $(30)$ days from receipt of such notice. this Lease shall thereupon terminate and it shall be lawful for the Lessor to enter into and upon the subleased area or any part thereof in the name of the whole to re-enter and the same to have again, repossess and enjoy, anything herein contained to the contrary notwithstanding; PROVIDED. HOWEVER, that the rights herein granted to the Lessor shall be in addition to and not in substitution for any other right or remedy which the Lessor may have with respect to any default by the Lessee.

The following is a typical example of a right of first refusal which might be found in the operating agreement:'

\section{RIGHTS OF FIRST REFUSAL CLAUSE}

2401 RIGHT TO ASSIGN, SELL OR DISPOSE - Subject to Clause 2402, a party shall not assign, sell or dispose of any of its participating interest in the joint lands (other than as required and allowed one party to another elsewhere in this Operating Procedure) without first complying with the provisions [as follows]:

...

\section{ALTERNATE B}

If a party (in this Article called "the selling party") wishes to assign, sell or dispose of, or has received an of fer which it is willing to accept for the assignment, sale or disposition of all or part of its interest in all or part of the joint lands (in this Article called "the subject interest'"), the selling party shall give notice thereof to the other parties (in this Article called "the offerees"). The selling party's notice shall contain the terms and conditions of the proposed assignment, sale or disposition, including the consideration to be received for the subject interest and. if applicable, the name of the offering party. The offerees shall have the right for a period of twenty (20) days after receipt of the notice from the selling party (in this Article called "the notice period"), 10 elect in writing to acquire the subject interest from the selling party on the terms and conditions contained in the notice. The offerees so electing to acquire the subject interest (in this Article called "the buying parties") shall be obligated to acquire the subject interest in its entirety. The buying parties shall have the right to acquire the subject interest in the proportions that their respective participating interests bear one to the other. If all the offerees decline or fail to elect within the notice period to acquire the subject interest. the selling party shall be free for a period of sixty $(60)$ days next following the expiry of the notice period, to assign, sell or dispose of the subject interest on the terms and conditions and to the offering party (if applicable) stipulated in its offer, but not after the said sixty (60) day period, nor otherwise than so stipulated, without again complying with the provisions of this Article.

If the consideration stipulated in the offer for the subject interest is one which cannot be matched in kind by the offerees, the selling party may set out in its notice its bona fide estimate of the value in cash of the said consideration. If the selling party's notice did not include its bona fide estimate as aforesaid, the offerees, or any of them, may request such estimate, in which event the notice period shall be suspended until such estimate is received by all of the offerees. In case of dispute as to the reasonableness of the estimate, the matter shall be referred to arbitration under the provisions of the Arbitra. tion Act or Ordinance of the province. state or territory where the joint lands are situated, but the notice period shall not be extended by such referral of the dispute to arbitration. If the equivalent cash consideration determined by the arbitration is lower than the estimate submitted by the selling party, the cash consideration determined by arbitration shall be the sale price for the subject interest and the accounts of the selling party and the buying parties shalt be adjusted accordingly; if the equivalent cash consideration determined by arbitration is higher than the estimate submitted by the selling party. the estimate submitted by the selling party shall be the sale price for the subject interest.

1. Canadian Association of Petroleum Landmen. "1981 C.A.P.L. Operating Procedure" at Clause 2401. 
This paper will examine the nature and validity of these provisions restricting alienation in connection with oil and gas transactions. For that purpose, the applicability of landlord and tenant principles, the ability of the Courts to consider the framework of the oil and gas industry when construing these provisions, and the rights and obligations of each of the farmor, the farmee and $A$ inter se will be considered.

\section{THE NATURE OF AN OIL AND GAS LEASE AND THE APPLICABILITY OF LANDLORD AND TENANT LAW}

There is a limited body of law establishing the legal nature and effect of the above or similar provisions when contained in an oil and gas lease or farmout agreement. Because of the lack of law specifically applicable to oil and gas instruments, there is a tendency among practitioners to look to the law of landlord and tenant as a guide in such matters. While agreements evidencing ownership of oil and gas rights are referred to as oil and gas "leases", several factors must be taken into account before landlord and tenant doctrines may be applied to oil and gas problems.

Ross J. of the Saskatchewan Court of King's Bench cautioned against applying landlord and tenant principles to an oil and gas lease in Kendall v. Smith and Northern Royalties Limited. ${ }^{2}$ His Lordship cited Lord Cairns in Gowan v. Christie ${ }^{3}$ in support of the following proposition, and stated:4

\section{[A] lease of mines is}

"not, in reality, a lease at all in the sense that we speak of an agricultural lease. There is no fruit; that is to say, there is no increase, there is no sowing or reaping in the ordinary sense of the term; and there are no periodical harvests. What we call a mineral lease is really ... . a sale out and out of a portion of land . . . and to get certain things there if he can find them, and take them away, just as if he had bought so much of the soil."

In Coltness Iron Co. v. Black (1881) 6 A.C. 315. 51 LJQB 626, Lord Blackburn at p. 335 quoted the above passage from the judgment of Lord Cairns and spoke of it "as a perfectly accurate statement."

Having in mind the above cases, and the fact that there does not appear to be any difference in principle between a right to take minerals and a right to take oil and gas from land, I seriously doubt whether the statutory law or the common law in respect to landlord and tenant can be applied to such contracts at all.

However, the courts of Alberta. where these documents are more common than in this province, have for some years been applying the law of landlord and tenant in establishing the rights of the parties to such contracts.

There is a fundamental distinction between a land lease (i.e. a lease which entitles the lessee to quiet enjoyment but prohibits waste) and an oil and gas lease. The freehold oil and gas lease was characterized by the Supreme Court of Canada in Berkheiser v. Berkheiser ${ }^{5}$ as a profit-à-prendre, that is, as an incorporeal, rather than a corporeal, right: ${ }^{6}$

The word "lease" in its ordinary meaning implies in relation to land the possession of an indestructible substance . . . For oil and gas . . . other modes of conveyance appropriate to a corporeal hereditament would not accord with the notion of ownership of those substances.

2. [1947] 2 W.W.R. 609 (Sask. K.B.).

3. (1873) L.R. 2 Sc. \& Div. 273 (H.L.).

4. Supran. 2 at 613.

S. (1957) 7 D.L.R. (2d) 721 (S.C.C.).

6. Id. at 725-726. 
The idea suitable to the partial use of the surface of lands as a necessary means of seeking for and drawing off these fluid substances. apart from the influence by analogy of existing concepts related to different substances, is that of operations to reduce to possession something by its nature generally ready for flight, which, as embodying a property interest, is adequately symbolized by the general term incorporeal right. The word 'grant', then, not being significant of title, and the word 'lease' not carrying with it the possession with which it is ordinarily associated, we look to the detailed description of the acts authorized for the true intendment of the instrument and doing that here I interpret it as either a profit à prendre or an irrevocable licence to search for and to win the substance named.

The key elements of an oil and gas lease - the underlying "conditions" - are the covenants to develop the premises, to protect the premises against drainage, to market the product and to pay to the lessor a royalty. Under the standard covenant to develop (the drilling clause) in an oil and gas lease - the "unless" clause - if the lessee fails to pay, or assigns to a third party who fails to pay, the delay rental, the lease terminates automatically. There is no basis for holding the lessee or its assignee responsible for delay rentals. The "unless" clause is a condition of the continuance of the lease and not a mere covenant. Breach of the "unless" clauses, as does the breach of a condition, results in the automatic termination of the lease.?

Two other factors are important to consider when discussing the nature of an oil and gas lease: ${ }^{\mathbf{p}}$

One is the . . e element of frequency - if not promiscuity - of transfer of oil and gas leases. The other is that covenants which are normally imposed only by implication are perhaps the most important obligations of an oil and gas lease.

Further, as another author has noted: 9

One of the most distinctive features of oil and gas leases is the almost total absence in the ordinary type of lease of express clauses protecting the royalty interest of the lessor. It is doubtful if any other character of legal instrument can be found in which one of the parties has so much potentially at stake with so little express contractual protection.

By contrast, failure to pay rent in a landlord and tenant situation does not result in the automatic termination of the lease and can be relieved against in certain circumstances. Caution must, therefore, be taken in using landlord and tenant principles when assessing the legal nature of any provision of an oil and gas lease or a farmout or operating agreement. The object of the contract must be considered.

Canadian courts have recognized that the circumstances surrounding a contract are important to its interpretation. W.H. Hurlburt, in his article "Judicial Approach to the Petroleum and Natural Gas Lease", 10 cites several examples, including Toronto Railway Company v. City of Toronto as, follows:"

In construing an instrument in writing, the court is to consider what the facts were in respect to which the instrument was framed, and the object as appearing from the instrument, and taking all these together it is to see what is the intention appearing from

7. Lewis and Thompson, 1 Can. Oil \& Gas Law, Butterworths, at 104.

8. W. Warren. "Transfer at the oil and gas lessee's interest" (1956) 34 Texas L. Rev. 386 at 399.

9. A. Walker, "The Nature of the Property Interests Created by an Oil and Gas Lease in Texas". (1933) II Texas L. Rev. 399 at 399.

10. (1965) 4 A.L.R. 196 at 197.

I1. (1906) 37 S.C.R. 430 at $434-435$. 
the language when used with reference to such facts and with such an object, and the function of the court is limited to construing the words employed: it is not justified in forcing into them a meaning which they cannot reasonably admit of.

Hurlburt also states: ${ }^{12}$

It may therefore be taken to be good law that Canadian courts, in construing a contract. should look at the circumstances surrounding execution of the contract and the objects which are to be attained by it.

This principle was followed in the case of Mercury Oils Ltd. v. Vulcan-Brown Petroleums Ltd., ${ }^{13}$ where the Supreme Court of Canada was required to construe various provisions of an oil and gas lease. The lease contained a development clause requiring the drilling of two wells. The second well could not conform with spacing regulations and accordingly, no well license could be obtained. The lease provided that a failure to drill the second well would result in forfeiture of the lands except for the area on which the first well was located and five acres surrounding it. Hudson J. viewed all of the circumstances and concluded as follows: ${ }^{14}$

Reading all of these provisions together as we must, can it be said that the plaintiff is in default within the contemplation of clause 28 ? I do not think so.

The present is not a case of frustration or of unjust enrichment. There is no total failure of consideration. The plaintiff has paid the money in rental in the past and is under an obligation to pay it in the future. The plaintiff is, so far as we know, operating the first well and paying the defendant the royaity on production provided for by the sublease. Nor is it shown that there is any special hardship imposed on the defendant. It does not appear that the defendant could get a license to drill where the plaintiff has failed. If the regulations are altered to permit the drilling of another well. then both parties will profit. The defendant will get the royalty; and the plaintiff the remaining share of the products.

The Mercury Oils decision is helpful. It is consistent with Hurlburt's proposition and is authority that Canadian courts, when construing contracts relating to the ownership and operation of oil and gas interests, should look at the industry, its practices and the nature of the instrument, when determining the rights of the parties, rather than simply applying landlord and tenant principles.

The effect of an assignment by the farmee to A cannot be construed in a vacuum. A literal interpretation of the default provisions would lead to the conclusion that a breach of a restriction against alienation provision entitles the farmor to terminate the interest of the farmee and A. Given the business purpose of a lease and a farmout agreement, the right of reentry provision in a lease must not be interpreted strictly according to landlord and tenant principles. Given the frequency with which unapproved transfers occur within in the industry, such as from the farmee to $A$, it is submitted that the courts must look carefully at the effect of enforcing re-entry provisions in oil and gas leases where a breach of a clause restricting assignment has occurred. Where a well has been drilled, enforcement of a right of re-entry against the farmee or $A$ would result in the unjust enrichment of the farmor.

12. Supra n. 10 at 198.

13. [1943] S.C.R. 37.

14. Id. at 41 . 
In Kendall v. Smith, ${ }^{15}$ the Court was interpreting an agreement which contained no provision for re-entry. Nevertheless, the Court determined that the lessee was entitled to relief against forfeiture. The Supreme Court of Alberta, in Risvold v. Scott and Granville Oils Limited ${ }^{18}$ and Oil City Petroleums (Leduc) Ltd. et al. v. American Leduc Petroleums Ltd. et al., 17 has dealt with relief against forfeiture. In Granville Oils relief against forfeiture was granted, notwithstanding an express provision for re-entry. The Court held that the terms of the lease were "substantially performed" and that forfeiture should be relieved against. In American Leduc Petroleums relief against forfeiture was not granted, because the Court concluded that an essential or fundamental term of the lease had been breached. It follows then that a court must look at the effect of the breach (i.e. was the breached term fundamental) before determining whether or not a provision relating to forfeiture will be enforced or whether relief will be granted.

\section{ASSIGNABILITY OF CONTRACTUAL RIGHTS AND PRIVITY OF CONTRACT}

In determining the rights of the assignee " $A$ " in connection with the lease and the ability of $A$ to assert certain rights against the farmor, the right of the farmee to assign its rights under the farmout agreement must first be established. If the farmout agreement is assignable, $A$ will wish to determine whether it has a right to, or in, the subject matter of the contract (i.e. the lease) or whether it is bound by, or able to enforce or cause to be enforced any rights under the farmout agreement or the operating agreement.

Principles of contract law relating to the assignability of contractual rights are discussed in various texts. For example Fridman in The Law of Contract in Canada, indicates that: ${ }^{18}$
Contractual rights were unassignable at common law, any more than other choses in ac- tion, if by this is meant that the assignee was thereby enabled to sue the debtor for recovery of the debt or other benefit under the contract in his, the assignee's own name. If a purported assignment occurred, the assignor would still have to sue to recover. though what was recovered would enure to the benefit of the assignee.

General principles of contract law provide that a party obligated under a contract always has the obligation to perform. A party may assign rights but not liabilities unless the assignee becomes a party to the contract and assumes (and is accepted to have assumed) those obligations. In The Queen v. Smith, Strong J. illustrates this principle:19

(A) party who enters into a contract for the performance of work is not entitled by a mere assignment to another person to substitute the assignee for himself, so as 10 delegate to the assignee his own rights and liabilities under the contract, without the consent of the other party to the agreement, is a proposition of law so well established that it requires scarcely any authority to support it. In such a case there is no priority of contract - no contractual relation of any kind - between the assignee and the party for whom the work is to be performed.

15. Supran. 2.

16. [1938] I W.W.R. 682 (Alta. S.C.T.D.).

17. [1951] 3 D.L.R. 835 (Alta S.C.A.D.): aff'd |1952] 3 D.L.R. 577 (S.C.C.).

18. G. Fridman. The Law of Contract in Canada (1976) at $432-433$.

19. (1883) 10 S.C.R. 1 at 55. 
Courts of equity developed certain exceptions to the principle of unassignability. The proper limits of these exceptions are not yet clearly settled and have not been given any definitive judicial consideration in the context of agreements relating to oil and gas rights. ${ }^{20}$

One exception is the ability of a contracting party to have his obligations performed by a third party. Cote points out that: ${ }^{21}$

[u]nless a contract either expressly or by implication shows that it is to be performed only by the party to it, as where it is for skilled personal services such as singing or painting, anyone may perform the contract on behalf of the one who made the contract.

Cote relies on the case of British Waggon Co. v. Lea ${ }^{22}$ to conclude that: ${ }^{23}$

[i]f the subcontractor or substituted performer performs the contract properly, that is due performance and both frees the contracting party from liability and also earns him his remuneration.

Lessees and farmees frequently contract with persons who are not party to the original contract pursuant to which the other party pays for or performs the obligations under the lease or farmout agreement. Do the contract law principles respecting assignment apply in the context of an oil and gas lease or farmout agreement? It is' submitted that when a farmee or lessee accepts participation for drilling costs from a third party, such as $A$, the farmee is thereby substituting A's performance for the farmee's performance. Such substitution should not affect the farmee's entitlement to earn under the farmout agreement. If, however, in consideration for $\mathbf{A}$ having performed or contributed to the performance of a farmee's obligations, $A$ is entitled to receive from the farmee an interest in the rights earned by the farmee and the underlying farmout agreement or lease contains a restriction against alienation, does $\mathrm{A}$ have either an enforceable or a defensible right to an interest in the lease?

There is clearly no privity of contract between the farmor and A. Cote discusses a number of exceptions to the rules relating to privity of contract and the ability of a third party to enforce a contract to which it is not a party. ${ }^{24}$ They include trusts and restrictive covenants relating to land. $A$, as the assignee, would have no right to enforce the contract against the farmor as none of the exceptions to privity would apply.

In a participation of the sort described in the Introduction to this paper, it is customary for the farmee to hold A's interest in trust for A. Trusts are enforceable by their beneficiaries. Both contractual rights and land can be the subject of a trust. Cote ${ }^{25}$ cites Fletcher v. Fletcher ${ }^{26}$ as authority for the proposition that a third party, such as A, who is the beneficiary of a trust, can compel a party, such as the farmee, to bring a suit to seek enforcement of the contract between the farmee and farmor.

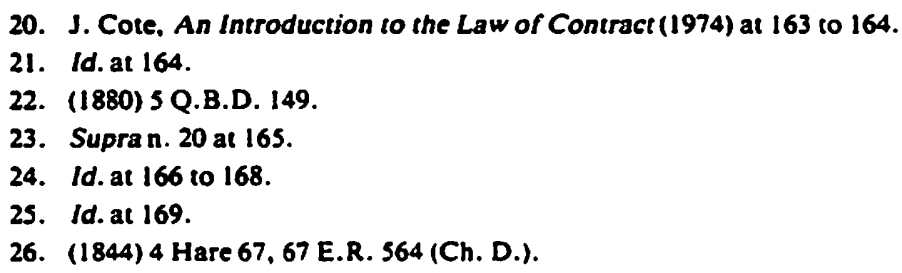

20. J. Cote, An Introduction to the Law of Contract (1974) at 163 to 164.

21. Id. at 164 .

22. (1880) 5 Q.B.D. 149.

23. Supran. 20 at 165.

24. Id. at 166 to 168.

25. Id. at 169.

26. (1844) 4 Hare 67, 67 E.R. 564 (Ch. D.). 
It appears, however, that the farmor cannot sue $A$ for breach of a term of the farmout agreement or of the participation agreement. The restriction against alienation contained in the farmout agreement should not impair A's ability to earn part of the farmee's interest. ${ }^{27}$

However, if the restrictions against alienation contained in either the lease, the farmout agreement or the operating agreement were construed to be "restrictive covenants", they might bind A. Restrictive covenants may extend to subsequent purchasers of the land, provided that those purchasers had notice of the restrictions at the time they acquired their interests. ${ }^{28}$

\section{RESTRICTIVE COVENANTS}

The case of Mus v. Matlashewski ${ }^{29}$ provides that where a contract, such as the farmout agreement, contains a restriction on the right of a party to assign it, any assignment which constitutes a breach of the covenant not to assign leaves $A$ as assignee with no rights as against the farmor. A distinction must be drawn between the subject matter of a contract (i.e. an interest to be earned under the farmout agreement) and the rights and obligations of a contractual nature (i.e. a requirement for consent to the assignment of the agreement). The same distinction must be drawn between the covenants in an oil and gas lease which are merely contractual in nature, and those which "touch and concern the land and run with the land". It is submitted that, once earned, an interest in an oil and gas lease is assignable without regard to the covenant not to assign contained in the farmout agreement.

An oil and gas lease may contain restrictions against its assignment. The distinction between contractual covenants which bind the lessor and lessee, on the one hand, and the interest in land (profit à prendre) granted thereby, on the other hand, becomes fundamental. Unless the restriction against alienation is a covenant running with the land (attaching to and forming a part of the oil and gas rights) such a restriction will not affect or bind an assignee such as $\mathrm{A}$. The farmor would have no right to compel $A$, having earned its interest, to reconvey that interest to the farmor.

Where no privity of contract exists, restrictions against alienation, to bind an assignee, must be enforceable and must be covenants which run with the land. Section 150 of the Land Titles Act of Alberta provides: ${ }^{30}$

150 (1) Any contract in writing for the sale and purchase of any land, mortgage or encumbrance is assignable notwithstanding anything to the contrary therein contained, and any assignment of any such contract operates according to its terms to transfer to the assignee therein mentioned all the right, title and interest of the assignor both at law and in equity, subject to the conditions and stipulations contained in the assignment.

(2) Nothing in this section shall be deemed to affect any rights at law or in equity of the original vendor or owner of the land, mortgage or encumbrance, until notice in writing of the assignment has been ejther sent to him by registered mail or served on him in the way process is usually served, and the notice mentioned in section 134 shall be deemed to be such notice.

27. Supran. 20 at 169.

28. Id. at 163.

29. [1944] 4 D.L.R. 522 (Man. C.A.).

30. R.S.A. 1980 , c. L-5. s. 150. 
To the extent that they are patented by the Crown, oil and gas rights are included in the definition of "land" under the Land Titles Act." Cote states: 32

It is inherent in our system of ownership of land or chattels that they be freely transferable, and therefore a complete prohibition on the sale of such an interest, contained in a grant of that interest [e.g. in an oil and gas lease] is considered to be repugnant to the grant itself, so that either the grant or the prohibition, probably the latter. will be void.

It follows that a prohibition, in contradistinction to a restriction, against transfer of an oil and gas interest, may be void.

A number of cases support the proposition that restrictions against alienation of the sort referred to in the introduction to this paper are not covenants running with the land. The most notable case is the Supreme Court of Canada's decision in Canadian Long Island Petroleums Ltd. et al. v. Irving Industries (Irving Wire Products Division) Ltd. et al. ${ }^{33}$ In that case, the Court was determining the rights of various parties two of whom were parties to a contract which contained a right of first refusal. The facts were as follows: $X \& Y$ had entered into an agreement which contained a right of first refusal similar in substance to the one set out in the introduction to this paper. $Y$ wished to sell its interest to $Z$, and entered into an agreement in that regard. $Y$ notified $X$ of its intention to sell to $Z$, and carried on with the sale. $X$, wishing to exercise its right of first refusal under its contract with $Y$, sought to have the agreement between $Y$ and $Z$ set aside. The Court, in discussing the parties' rights, drew some interesting and useful conclusions regarding the legal nature of such provisions. Martland J. stated that the right of first refusal did not give $\mathrm{X}$ any present right to require a future conveyance of $Y$ 's interest in the oil and gas rights: "It was not specifically enforceable at the time the agreement was executed." $34 \mathrm{X}$ was not given any right to take away $Y$ 's interest without its consent. Clause 13 of the agreement between $X$ and $Y$ provided that if $Y$ was prepared to accept an offer to sell its interest, $X$ would then, and only then, have a 30-day option to purchase on the same terms. His Lordship held that Y's right under the clause was a contractual right only: ${ }^{35}$

\begin{abstract}
In my opinion the right conferred by $\mathrm{cl} .13$ of the agreement in question here did not create property rights. Each party agreed that upon the occurrence of a certain event, which was within its own control, the other party would have a first right of purchase for a 30-day period. As mentioned previously, the clause is a part of an agreement between joint owners of a property, governing the operation and development of it. In essence it is a negative covenant whereby each party agrees not to substitute a third party as a joint owner with the other, without permitting the other party the opportunity. by meeting the proposed terms of sale, to acquire full ownership.
\end{abstract}

The Court concluded that the language must be read in context. The provision was held to be a negative covenant for the benefit of X's undivided interest. The language was not to be taken to create a "restrictive covenant" running with the land. The benefit was to X, not to the land.

31. Id. at s. I(n).

32. Supra $\mathrm{n} .20$ at 178 . Cote relies on Metcalfev. Metcalfe (1889) 43 Ch. D. 633 and Siogdonv. Lee $[1891]$ 1 Q.B. 661 at 670 (C.A.).

33. $[1974] 6$ W.W.R. 385 (S.C.C.).

34. Id. at 399.

35. Id. at 401 . 
The Court ordered specific performance of the contract between $X$ and $Y$, to relieve against what appeared to be a conspiracy between $Y$ and $Z$.

The conclusions in the Long Island case accord with the general contract principles enunciated earlier. The Court does not conclude that the farmout or operating agreement binds $X$ but only that the farmor is entitled to have the farmee perform its obligations under those agreements.

This analysis and the Long Island case ${ }^{38}$ were applied by the Supreme Court of Canada in McFarland v. Hauser. ${ }^{37}$ Applying these principles to the facts set out in the introduction, the Court would conclude that the farmor was entitled to specific performance, against the farmee, of the contract with the farmee because $A$ had knowledge that the terms of the contract between the farmor and farmee were about to be breached. In both the Long Island and the McFarland cases, the Supreme Court of Canada was sensitive to the fact that A knew of the terms of the contract. While A was not bound by the terms of the contract, the farmor's contractual rights against the farmee defeat in equity any contractual rights which $A$ had to compel the farmee to perform under the participation agreement. Where $A$ has no knowledge of the terms of the agreement between the farmor and farmee, or where there are other parties claiming an interest from the farmee, it would appear that once $A$ has received its interest, $\mathbf{A}$ takes that interest without any right of the farmor to defeat the same.

There does not appear to be any decided case determining the legal nature of a requirement for consent to an assignment of a farmout agreement or an oil and gas lease. As such a provision does not allow a party (such as the lessor or farmor) to compel the other party (the lessee, farmee or assignee) to convey its interest to him, a requirement for the consent to a transfer or assignment cannot be.any more than a mere contractual right. It is not a covenant running with the lantd and thus does not burden a successor.

Landlord and tenant law, as well as certain cases concerning estates in fee, has taken a somewhat different approach to requirements for consent to assign in agreements relating to oil and gas. In connection with estates in fee, the most of ten quoted decision is that of the Supreme Court of Canada in Alexander v. Killop \& Benjafield. ${ }^{30}$ Anglin J. enunciated the facts and then described the nature of the party's interest: ${ }^{39}$

The facts of the case are briefly but sufficiently summarized by Newlands. J.. as follows:

"The plaintiff first obtained an equitable estate in the said half section of land. Subsequently, but without notice of the plaintiff's equitable estate, the defendants. McKillop and Benjafield, also obtained an equitable estate in the said land. Before anything further was done by the said defendants the plaintiff filed a caveat in the proper Land Titles office against the said lands, after which the said defendants completed their purchase and had the assignment to them approved of by the owner of the legal estate."

Apart from the effect of the Land Titles Act of Saskatchewan (6 Ed. VII, Ch. 24) and of the caveat lodged by the plaintiff pursuant to its provisions. I incline to the view that the defendants would have been entitled to succeed, because, although subsequent pur-

36. Id.

37. [1979]1 S.C.R. 337.

38. (1912) I W.W.R. 871 (S.C.C.).

39. Id. at 877. 
chasers, they had the best right to call for a conveyance of the outstanding legal estate and were therefore in equity entitled to its protection. Dart on Vendors \& Purchasers, 7 ed. p. 845. They held this position not because they had given notice of their purchase to the holder of the legal estate, which the plaintiff had omitted to do. Hopkins v. Hemsworth, 1898, $2 \mathrm{Ch}$. 347, nor because the plaintiff had omitted to have a note of his purchase endorsed on the original contract from the railway company, Jones $v$. Jones, 8 Simons, 633 (points much insisted on at bar), but because they had obtained the consent of the railway company to the assignment to them of their vendor's interest in the land. As a result of the original sale the railway company became a trustee of the property for its purchaser, who in the eye of a court of equity, was the real beneficial owner, Shaw v. Foster, L.R. S H.L. 321, 338. The defendants were purchasers of his interest for value and without notice of the plaintiff's claim. They procured the railway company to become a party to the conveyance to them of that equitable interest by obtaining its consent to the assignment under which they claim. Although the company did not formally convey or declare a trust of the legal estate in favor of the defendants. its privity and consent to the assignment to them gave them a position which (apart always from the effeet of the Land Titles Act and of the caveat lodged by the plaintiff under it) was such that a court of equity would not interfere to deprive them of the better right so obtained to call for the conveyance of the real estate, Wilkes v. Boddington, 2 Vernon, 599; Wilmot v. Pike, S Hare, 14, 22; Taylor v. London \& County Banking Co., 1901, $2 \mathrm{Ch}$. 231, 262-3. The effect of this consent of the railway company on the defendants' rights is certainly not lessened by the presence in the company's original agreement for sale or the following special clause:

"No assignment of this contract shall be valid uniess the same shall be for the entire interest of the purchaser, and approved and countersigned on behalf of the company by a duly authorized person, and no agreement or conditions or relations between the purchaser and his assignee or any other person acquiring title or interest from or through the purchaser shall preclude the company from the right to convey the premises to the purchaser, on the surrender of this agreement and the payment of the unpaid portion of the purchase money which may be due hereunder, unless the assignment hereof be approved and countersigned by the said company as aforesaid."

It would follow then, that if we introduce a competing agreement between the farmee and a fourth party, "C", whereby the farmee agrees to convey the same interest to the fourth party as the farmee has agreed to convey to $\mathrm{A}$, and if the fourth party obtains the consent of the farmor, A's interest may be defeated. The Alexander case goes on, however, to suggest that if $A$ filed a caveat protecting its interest, the fourth party's claim would be defeated. This suggests that, whenever freehold lands are involved, a fourth party in the position of $C$ should register a caveat to record its interest.

The Alexander case is important. It seems to make clear that while the interest of A may be defeated, it is not defeated merely by a failure to comply with a requirement for consent. Brown C.J.K.B. points out that A "has an equitable interest in the property notwithstanding that the assignment was not approved." 40

The cases of Atlantic Realty Co. Ltd. et al. v. Jackson ${ }^{41}$ and In re The Land Titles Act (Massey-Harris Company, Limited's case) ${ }^{42}$ held that "the assignee of a purchaser of land under a contract containing [a requirement for consent] had no status to file a caveat". ${ }^{43}$ This line of authority seems to be bad law. The Court in the Atlantic Realty case

40. Fitzpatrick v. Fitzpatrick [1923] 1 W.W.R. 1188 at 1189 (Sask. K.B.), relying on McDougallv. Mckay64 S.C.R. 1.

41. (1913) 5 W.W.R. 535 (B.C.C.A.).

42. [1922] I W.W.R. 816 (Sask. C.A.), relying on Atlantic Realty Co. Ltd. v. Jackson, id.

43. Id. at 818 . 
relies on the authority of the dissenting judgment in Alexander v. McKillop. ${ }^{44}$ The case is also inconsistent with an equitable estate being an interest in land.

\section{CONCLUSIONS}

If neither the right of first refusal nor the requirement for consent to an assignment is a covenant "running with the land", it follows that a breach of such provisions will entitle a party (the farmor, in our example) to damages rather than to a remedy in rem. The case of Masai Minerals Limited et al. v. Heritage Resources Ltd. et al. ${ }^{45}$ is illustrative of this proposition. The facts of the case are best set out in the headnote: ${ }^{46}$

In August 1971 the plaintiff $M$. and the defendant $H$. agreed that $H$. would assign to the plaintiff a gross overriding royalty of $S$ per cent with respect to oil and gas produced from a certain lease. $H$. and the defendant $T$. agreed that $H$. would be the operator; however, by further agreement dated $18 \mathrm{th}$ February $1972 \mathrm{~T}$. took over as operator and the lease was assigned to it. Also in February $1972 \mathrm{H}$. wrote to the Department of Mineral Resources surrendering the lease; the surrender was rescinded by telegram; the lease was surrendered by H. again, in March 1972. In December 1972 H. asked that the lease be reinstated, the Minister denied the request and $H$. obtained a new lease by bid in July 1973. T. did not become aware of the surrender until December 1972; T. brought an action against $H$. to which the plaintiff was not made a party, and $T$. was declared the owner of the lease subject to any existing overriding royalties.

The agreement between $M$. and $H$. contained a clause that stated that $H$. must give $M$. notice of any proposed surrender and give $M$. the option of having the lease assigned to it.

M. asked for a declaration that it was the beneficial owner of the lease. The trial judge refused to grant specific performance and awarded $M$. damages for any royalties lost. The plaintiff appealed.

\section{The Saskatchewan Court of Appeal concluded:47}

Heritage breached its agreement with Masai by surrendering the lease without first offering to assign it to Masai. After that breach it was not able to perform its obligation. Masai could have immediately brought action. Its relief however would be limited to an award of damages. . . . The right which Masai has under the covenant in question is not an interest in land: see Can. Long Island Petroleums Led. v. Irving Indust. (Irving Wire Products Division) Ltd., [1975] 2 S.C.R. 715, [1974] 6 W.W.R., 385. 50 D.L.R. (3d) 265. Therefore no interest in the land accrued to Masai by reason of the improper surrender.

While the Court concluded that the farmee was still obligated to pay a royalty to the farmor, the case supports the proposition that the farmor is entitled to damages for breach of the restriction against alienation, and is not entitled to compel the farmee or A to convey their respective interests to the farmor.

Where the conveyance by the farmee to $A$ gives the farmor a right of re-entry or a right of termination, relief against forfeiture appears to be available to the farmee. It is submitted that a court, in looking at a breach of a requirement for consent or a right of first refusal, should assess whether such term goes to the root of the contract or whether damages would be a sufficient remedy for the breach. As such provisions do not necessarily touch and concern the actual subject matter of the

\footnotetext{
44. Supran. 38.

45. [1981] 2 W.W.R. 140 (Sask. C.A.).

46. Id.

47. Id. at 144 and 146.
} 
lease, and usually do not affect any requirement to develop or pay "rent" (i.e. royalties), the best view seems to be that a court would probably decide that the interest is not terminated by breach of the requirement for consent or right of first refusal provision. A court in a proper case would probably be persuaded to grart relief against forfeiture. In addition, where production is continuing and a lessor is receiving a royalty, it would be difficult to establish that any significant damage had been suffered by a farmor or lessor as a result of a lessee assigning part of its interest to a third party in breach of a requirement for consent.

The conclusion appears to be that the restriction against alienation set out in the introduction to this paper does not bind a third party assignee of the farmee unless the third party has notice of the restriction. Whether the assignee has a duty to inquire into the terms of the lease, the farmout and operating agreement is the subject of another paper. As a preliminary comment the Supreme Court of Canada has stated that a duty rests on an assignee of a contract to inquire into the equities between the assignor and the other contracting party..$^{48}$ If any equities exist, the assignee may take subject to such equities ${ }^{49}$ such as agreed restrictions on the assignor's right of assignment. ${ }^{50}$

The assignee's (A's) interest is subject to being defeated by a subsequent purchaser from the farmee who obtains the farmor's consent. A's interest in the oil and gas rights is, until challenged by a successor to the farmee, retained as an equitable interest in the oil and gas rights. The farmee will have conveyed an equitable interest to the assignee notwithstanding that the assignee has no contractual rights against the farmor who is the holder of the legal estate. In the result, $A$ has no right to enforce any of the contractual covenants between the farmor and the farmee, but has a defensible right to the interests which $A$ has earned under the farmout agreement.

While practitioners cannot disregard restrictions against alienation, we should reassess our approach to such restrictions and should perhaps eliminate them wherever possible. Clients who are in the position of $A$ should be advised that their interests are best served by requiring the farmee to convey the legal (as opposed to the beneficial) title to the interests, by serving notice of A's interest on the farmor, and by having $A$ named as a lessee.

48. Canadian Admiral Corporation Lid. v. L.F. Dommerich \& Co.. (1964) S.C.R. 238 at 247.

49. Royal Bank of Canada v. Gustafson et al. (1924) I W.W.R. $\$ 44$ (B.C.S.C.T.D.).

SO. Hamilion v. Ralton (1925) 3 D.L.R. 1090 at 1092-1093, and 1102 (Sask. C.A.). 